\author{
ANTONI BARTOSZEK \\ Uniwersytet Śląski w Katowicach \\ Wydział Teologiczny
}

\title{
Odpowiedzialność za bliźnich w potrzebie w kontekście kategorii ordo caritatis (z uwzględnieniem problemu migracji)
}

W jaki sposób okazać miłość ludziom w potrzebie, w sytuacji, gdy jest ich zbyt wielu, byśmy mogli im pomóc? Komu pomóc, jeśli nie można pomóc wszystkim? Te ogólne pytania, przybierają bardziej dramatyczny kształt w konkretnych sytuacjach: W jakiej kolejności ratować osoby z pożaru? Komu pomóc medycznie, jeśli (finansowe i sprzętowe) możliwości służby zdrowia są ograniczone? Ten problem rozkłada się na wiele szczegółowych zagadnień, np. powstaje pytanie o moralne aspekty allokacji, czyli rozdzielania środków finansowych na poszczególne dziedziny medycyny; znany jest oczywiście problem kryteriów tworzenia kolejki potencjalnych biorców narządów (np. serca czy nerki) do przeszczepów. W kontekście biedy materialnej powstają pytania o sposób rozdziału żywności między potrzebujących, a wreszcie o zakres i formę pomocy imigrantom i uchodźcom.

Ewangeliczna koncepcja pomagania, jak zresztą cała religia chrześcijańska, ma charakter racjonalny. Racjonalny wymiar miłości wyraża się w tym, że nie wszystkich kochamy w ten sam sposób i nie wszystkim jesteśmy w stanie pomóc. Jako punkt wyjścia należy przywołać postawę Jezusa, który wytworzył wokół siebie określone kręgi osób: nauczał tłum, wybrał 72 uczniów, ustanowił ściślejsze grono 12 apostołów, jednego ucznia umiłował szczególnie. Spoza grona uczniów w sposób szczególny był zaprzyjaźniony z domem Łazarza. Uzdrawiał nie wszystkich, ale niektóre osoby.

Kręgi miłości można dostrzec również we wspólnocie pierwotnego Kościoła. Choć przesłanie Jezusa było uniwersalne, wzywające do otwarcia serca, także na człowieka spoza Izraela, a nawet na nieprzyjaciela, to jednak wy- 
raźnie widać szczególną wagę miłości wobec braci w wierze, określanej jako philadelphia oraz miłości wobec domowników: „A jeśli kto nie dba o swoich, a zwłaszcza o domowników, wyparł się wiary i gorszy jest od niewierzącego" (1 Tm 5,8). Wszystkie te biblijne fakty stały się podstawą wypracowania w tradycji chrześcijańskiej kategorii ordo caritatis, czyli kategorii porządku miłości.

Ta właśnie kategoria będzie przedmiotem niniejszych analiz. Najpierw zostanie ukazana od strony historycznej, a następnie zastanie zaprezentowana próba wykazania jej aktualności i możliwości odniesienia jej do problemów związanych z migracją.

Jeśli chodzi o semantyczny wymiar kategorii, warto już w tym miejscu zauważyć, że w literaturze pojawia się także określenie ordo amoris ${ }^{1}$. Wydaje się, że kategoria caritas jest lepsza: wskazuje bowiem na zakorzenioną w rozumie i woli postawę wobec drugiego, którego postrzega się jako wartość, wskazuje zatem na odpowiedzialność. Poza tym termin caritas słusznie kojarzy się wprost z dobroczynnością. Pojęcie amor natomiast wskazuje bardziej na komponentę emocjonalną, na miłość, która raczej „zdarza się”, „dzieje się" w dużej mierze niezależnie od woli człowieka. A przecież sam poryw serca, w sensie uczuć, nie wystarczy. Amor wymaga pogłębienia przez caritas i dlatego pojęcie ordo caritatis jest bardziej wewnętrznie spójne niż ordo amoris.

\section{Z historii ordo caritatis}

Początki kategorii ordo caritatis sięgają św. Augustyna (†430) i jego dzieła De doctrina christiana. W Księdze pierwszej pojawia się następujący tekst: „Sprawiedliwie i święcie żyje ten, kto właściwie ocenia rzeczy, to znaczy, czyja miłość jest na tyle uporządkowana, żeby ani nie kochał tego, czego nie należy, ani odwrotnie, nie zaniedbał miłować tego, co miłować trzeba"2. Warto w tym miejscu zwrócić uwagę na zwrot „właściwie ocenia rzeczy” (rerum integer aestimator), wskazujący na konieczność właściwego rozeznawania w miłości, a także na wyrażenie ,uporządkowana miłość” (ordinata dilectio), wskazujące na konieczność porządkowania miłości. W dalszej części wypowiedzi św. Augustyn rozwija myśl następująco: „Wszystkich należy jednakowo kochać, lecz ponieważ nie wszystkim możemy pomóc, więc trzeba pomagać tym, którzy ze

${ }^{1}$ Por. S. Pope, The order of love and recent catholic ethics: a constructive proposal, "Theological Studies" 52 (1991) nr 2, s. 256.

${ }^{2}$ Augustyn, De doctrina christiana - O nauce chrześcijańskiej. Tekst łacińsko-polski, księga pierwsza, XXVII 28, tłum. J. Sulkowski, Warszawa 1989, s. 33-34. 
względu na miejsce, czas albo inne okoliczności niejako losem są z nami bliżej złączeni"’3. Swięty Augustyn wskazuje na pewne okoliczności, które sprawiają, że z niektórymi osobami jesteśmy bardziej powiązani, lecz nie wchodzi głębiej w zagadnienie.

Święty Tomasz z Akwinu (†1274) w Summie teologicznej szeroko omawia zagadnienie ordo caritatis. Czyni to w traktacie $O$ miłości (II-II, q. 23-46). Kwestia 26. zatytułowana jest wprost $O$ porzadku miłości. W tej kwestii św. Tomasz stawia aż 13 pytań: (1) Czy jest jakaś kolejność w miłości? (2) Czy człowiek ma miłować Boga więcej niż bliźniego? (3) Czy więcej niż siebie? (4) Czy więcej siebie niż bliźniego? (5) Czy człowiek powinien więcej miłować bliźniego niż swoje ciało? (6) Czy jednego bliźniego bardziej niż drugiego? (7) Czy bardziej lepszego bliźniego, czy bliżej ze sobą związanego? (8) Czy bardziej związanego ze sobą pokrewieństwem, czy też z innych powodów? (9) Czy winien bardziej miłować syna niż ojca? (10) Czy winien bardziej miłować matkę niż ojca? (11) Czy bardziej żonę niż ojca czy matkę? (12) Czy bardziej dobrodzieja, czy też tego, komu dobrodziejstwa wyświadczył? (13) Czy kolejność pozostanie w ojczyźnie niebieskiej?4

Zanim zostanie tu przedstawiony porządek, który stworzył św. Tomasz, warto wskazać na istniejący już w tamtych czasach, na linii tradycji św. Augustyn - Piotr Lombard $(† 1164)$ poczwórny przedmiot miłości: miłość Boga dla Niego samego jako najwyższego dobra, miłość do siebie jako uczestnika chwały Bożej, miłość do bliźniego, również jako uczestnika ostatecznego szczęścia oraz miłość do własnego ciała ${ }^{5}$ Ważne jest rozróżnienie: miłość do siebie oraz miłość do własnego ciała. Ukazuje ono, że w tradycji tej istniało wyraźne rozróżnienie na wartości duchowe, czyli przede wszystkim zbawienie, oraz na wartości doczesne, cielesne. W nawiązaniu do tamtej tradycji mówi się dziś, że życie cielesne jest nie tyle wartością absolutną, ile wartością podstawową i można je oddać dla wartości wyższych (nauczanie Evangelium vitae jest $\mathrm{w}$ tym względzie niezwykle precyzyjne) ${ }^{6}$.

Po tych uwagach można teraz wyliczyć kolejność (porządek) miłości, jaką przedstawił św. Tomasz z Akwinu: miłość Boga, miłość siebie, miłość bliźniego, miłość do naszego ciała, miłość do ciała bliźniego; i następnie: miłość do rodziców, miłość do dzieci, miłość do żony, miłość do krewnych, miłość do ludzi, których bardziej znamy, miłość do obcych, miłość do wrogów. W po-

3 Tamże, księga pierwsza XXVIII 29, s. 35.

4 Tomasz z Akwinu, Suma teologiczna [dalej: STh], t. 16: Miłość (II-II qu. 23-46), thum. A. Głażewski, London 1967, zagadnienie 26, s. 75.

5 Por. E. Vansteenberghe, Charité. Les grandes écoles théologiques, w: Dictionnaire de Spiritualité, t. II, cz. 1, Beauchesne-Paris 1953, k. 599-600.

${ }^{6}$ Por. Jan Paweł II, Encyklika Evangelium vitae (25.03.1995), w: Encykliki Ojca Świętego Jana Pawła II, Kraków 1996, nr 47. 
rządku tym należy także poza widocznym pierwszeństwem dóbr duchowych nad materialnymi uwzględniać wartości moralne danych osób ${ }^{7}$.

Ten Tomaszowy porządek wymaga bardziej szczegółowych analiz. Tylko na kilka elementów zostanie zwrócona tu uwaga. Święty Tomasz nie jest pewny co do kolejności miłości rodziców i miłości dzieci. $Z$ jednej strony mówi, że najpierw winna być miłość względem rodziców z racji tego, że należy najpierw miłować dobra bardziej podobne do Boga (a rodzice dają początek życiu, a pierwotny początek jest w Bogu), ale z drugiej strony - najpierw winniśmy miłować dzieci, bo one są cząstką nas samych, a miłość siebie jest zaraz po miłości Boga. Podobną trudność ma św. Tomasz w hierarchii miłości względem rodziców i współmałżonka. I tak miłość do rodziców winna być pierwsza (z tej samej racji, co wyżej, gdyż rodzice dają początek życiu, a pierwotny początek jest $\mathrm{w}$ Bogu), $\mathrm{z}$ drugiej jednak strony mąż i żona stanowią szczególną łączność „tak już nie są dwoje, lecz jedno ciało” (Mt 19,6). Święty Tomasz próbuje tę trudność rozwiązać następującym stwierdzeniem: „Miłość do żony ma być mocniejsza, natomiast rodzicom należy okazywać większy szacunek" ${ }^{\prime}$. Wśród tych 13 pytań św. Tomasz nie stawia np. pytania: Czy bardziej należy miłować żonę (męża) czy własne dzieci? My dziś takie pytanie stawiamy, a odpowiedź na nie jest ważna z punktu życia małżeńsko-rodzinnego, a mianowicie miłość do współmałżonka jest ważniejsza, gdyż jest bardziej pierwotna w stosunku do samego dziecka jako owocu miłości, a także dlatego, że na wzajemnej miłości rodziców dzieci tylko skorzystają. Zostawiając $\mathrm{w}$ tym miejscu analizy dotyczące życia małżeńsko-rodzinnego, trzeba zaznaczyć, że dla naszych rozważań ważne jest inne miejsce ordo caritatis, a mianowicie kolejność: miłość do krewnych, miłość do ludzi, których bardziej znamy, miłość do obcych, miłość do wrogów.

Zagadnienie ordo caritatis św. Tomasz z Akwinu podejmuje także w kwestii 31. Pyta tam: Czy bardziej trzeba pomagać ludziom nam bliższym? ${ }^{9}$ Warto w tym miejscu szerzej przywołać jego odpowiedź:

Wydaje się, że nie, ponieważ: czytamy w Ewangelii Łukasza $(14,12)$ : „Gdy wydajesz obiad albo wieczerzę, nie zapraszaj swoich przyjaciół ani braci, ani krewnych". Otóż ci są najbliżsi, a zatem nie powinno się więcej świadczyć dobrodziejstw osobom bliskim, lecz raczej obcym i potrzebującym, bo ewangelia ta dodaje: „,kiedy urządzasz przyjęcie, zaproś ubogich, ułomnych” itd. $(14,13)$. [...] Jednakże Augustyn uczy: „,skoro nie jesteś w stanie pomóc wszystkim, pomagaj

7 Por. STh II-II qu 26, s. 75-100; S. Pope, The order of love and recent catholic ethics..., dz. cyt., s. 262-271.

8 STh II-II qu 26, art. 11, s. 95.

9 STh II-II qu 31, art. 3, s. 142-143. 
przede wszystkim, stosownie do okoliczności miejsca, czasu, czy potrzeby, tym, którzy są ci bliżsi niż ci, co są bliscy dzięki przypadkowi.

I dalej Tomasz odpowiada:

Łaska i cnota działają zgodnie z porządkiem ustanowionym mądrością Bożą. Otóż w naturze porządek natury domaga się, by co działa najpierw i mocniej, oddziaływało na rzeczy sobie bliższe; np. ogień ogrzewa przedmioty bliższe. [...] Bliskość między ludźmi zależy od tego, co ich między sobą wzajemnie łączy. Krewnych łączy wspólnota urodzenia, obywateli wspólnota państwowa, wiernych wspólnota duchowa, i tak dalej. Zatem dobrodziejstwo ma być świadczone w zależności od rodzaju wspólnoty. Mówiąc po prostu, bardziej należy każdemu świadczyć dobrodziejstwa należące do tego, co stanowi o większej bliskości. To jednak może ulegać zmianom zależnie od okoliczności miejsca czasu i spraw; w pewnych bowiem wypadkach bardziej należy pomóc obcemu, znajdującemu się w wielkiej potrzebie, niż własnemu ojcu, nie będącemu w tak wielkiej potrze$\mathrm{bie}^{10}$.

W słowach tych św. Tomasz krzyżuje problem kręgów bliźnich z problemem okoliczności i wielkości potrzeb, w jakich bliźni się znajduje. Do tego trzeba jeszcze dołożyć to, o czym była mowa wcześniej, a mianowicie uwzględnienie rozróżnienia na potrzeby o charakterze duchowym czy też duchowo-osobowym oraz na potrzeby cielesno-materialne. Te wszystkie wyznaczniki stały się punktem wyjścia do bardziej szczegółowych rozróżnień i podziałów. Choć wpisują się one w zbyt kazuistycznie ujmowaną teologię moralną (nieraz skomplikowaną i w dużej mierze nieaktualną), to jednak zawierają wiele cennych intuicji. Warto nad nimi, przynajmniej na chwilę, pochylić się, opierając się na dorobku jednego z autorów: Hieronima Noldina.

Autor ten w następujący sposób konstruuje podstawy bardziej szczegółowych norm. Przede wszystkim mówi, że porządek należy zachować w trzech dziedzinach: w dziedzinie osób, w dziedzinie dóbr oraz $\mathrm{w}$ dziedzinie potrzeb ${ }^{11}$. W dziedzinie osób istnieje następująca kolejność: Bóg, my sami oraz bliźni. Każdy winien miłować Boga ponad wszystko, ponieważ dobroć Boga przewyższa wszystkie inne dobra. Na drugim miejscu każdy winien miłować siebie, ponieważ z woli Chrystusa miłowanie siebie jest miarą miłości bliźniego. Uporządkowana miłość zaczyna się od siebie samego, czyli miłującego. Wreszcie każdy powinien miłować bliźnich ${ }^{12}$. W tej dziedzinie kluczowe

10 Tamże.

11 H. Noldin, Summa theologiae moralis iuxta codicem iuris canonici, Vol. II: De praeceptis Dei et Ecclesiae, Lipsk $1939^{26}$, s. 79.

12 Por. tamże. 
wydają się dwa zagadnienia: priorytet miłości względem Boga ${ }^{13}$ oraz właściwe rozumienie miłości siebie, pojmowanej nie jako egoizm, ale jako wyraz wdzięczności za dar życia i za inne dary, które człowiek otrzymał od Boga. We współczesnej psychologii mówi się o akceptacji siebie i o pozytywnym spojrzeniu na siebie i swoje własne zasoby ${ }^{14}$.

Drugą dziedziną, w której należy zachować porządek, jest dziedzina dóbr. Według Noldina można wyróżnić trzy typy dóbr: duchowe, które dzieli na nadprzyrodzone (życie wieczne, łaskę Bożą, cnoty wlane) oraz naturalne (rozum, wolę, wolność), dobra cielesne wewnętrzne (życie, zdrowie) oraz dobra zewnętrzne, z których jedne są dobrami osoby (cześć, sława), a inne dobrami położenia (bogactwa). Wśród tych dóbr każdy powinien kochać dobra bardziej znakomite: bardziej duchowe niż cielesne, bardziej cielesne niż zewnętrzne, przy czym dobro wspólne jest większe niż dobro osobiste ${ }^{15}$. W odniesieniu do współczesności rodzi się $\mathrm{w}$ tym miejscu pytanie o hierarchię wartości w życiu człowieka, a precyzyjniej o hierarchię wartości w życiu chrześcijanina. Od strony obiektywnej na pierwszym miejscu hierarchii wartości stoi zbawienie w Jezusie Chrystusie. Dziś ta hierarchia wartości jest zaburzona (także niestety w życiu chrześcijan, a nawet w niektórych działaniach Kościoła) i na pierwszym miejscu stawia się $\mathrm{w}$ wymiarze indywidualnym zdrowie i dobrobyt materialny, a w wymiarze społecznym - pokój i tolerancję.

Trzecią dziedziną, w której należy zachować porządek, jest dziedzina potrzeby, a dokładnie jej wielkości. Hieronim Noldin mówi o trzech rodzajach potrzeb: skrajnej, ciężkiej oraz lekkiej (inaczej nazywanej wspólną). Potrzeba skrajna to taka, w której człowiek nie może uniknąć pomocy drugiego; ciężka

${ }^{13}$ Por. M. Viller, H. Monier-Vinard, Charité. Charité envers le prochain, w: Dictionnaire de Spiritualité, dz. cyt., k. 655-657. W jedynej bodajże wypowiedzi Jana Pawła II, w której pojawia się kategoria ordo caritatis, zostaje odniesiona właśnie do pierwszeństwa miłości względem Boga. „Św. Rafał Kalinowski w sposób wyrazisty ukazuje całym swym życiem, czym jest to pierwsze i największe przykazanie, które Chrystus potwierdził mocą swych czynów i słów, a nade wszystko ofiarą swego krzyża. «Będziesz miłował Pana Boga swego całym swoim sercem, całą swoją duszą i całym swoim umysłem [...], (a) swego bliźniego jak siebie samego» (Mt 22,37.39). Temu przykazaniu odpowiada wewnętrzna miara człowieka. Człowiek jest wolny dlatego, aby miłował. A miłość ma właściwą sobie hierarchię: ordo caritatis. Jakże ktoś może miłować Boga, którego nie widzi, jeżeli nie miłuje brata, którego widzi? - pyta apostoł (por. $1 \mathrm{~J} 4,20$ ). Ale nie może być też miłości brata, miłości człowieka, bez otwarcia wolnej ludzkiej woli w kierunku tego dobra, które jest najwyższe. Tym dobrem jest sam Bóg, choćby nawet człowiek nie umiał Go nazwać po imieniu. Nie można z życia ludzkiego wyrywać tego porządku: ordo caritatis, jeśli nie chce się człowieka pomniejszyć i okaleczyć" - Jan Paweł II, Przemówienie podczas audiencji dla pielgrzymów przybytych na kanonizację św. Rafała Kalinowskiego (18 listopad 1991) ), „L'Osservatore Romano” 11 (1991) nr 12, s. 26.

14 Por. K. Glombik, Miłość Boga, bliźniego i samego siebie - przykazanie i postawa, „Teologia i Moralność" 6 (2009), s. 83-89; J. Rońda, Miłość samego siebie w kontekście życia społeczno-gospodarczego, „Sosnowieckie Studia Teologiczne” 11 (2013), s. 136-138.

15 Por. H. Noldin, Summa theologiae moralis..., dz. cyt., s. 79-80. 
- to taka, z której bez pomocy innego może uwolnić się tylko z wielką trudnością, lekka - to taka, z której może uwolnić się bez wielkiej trudności ${ }^{16}$. W tej trzeciej dziedzinie ocena sytuacji bywa nieraz bardzo trudna: wymaga dużej roztropności, a czasami bardziej specjalistycznych narzędzi.

Na podstawie porządku w trzech wyżej wymienionych dziedzinach o. Hieronim formułuje szereg szczegółowych norm w ramach ordo caritatis. Tutaj warto wymienić tylko niektóre z nich, a mianowicie, człowiek powinien troszczyć się o swoje zbawienie i nie może pomagać bliźniemu, popełniając zło moralne. Można jednak w celu pomocy bliźniemu narażać się na zło moralne, jednak przy zachowaniu środków ostrożności, by grzechu nie popełnić. Dla naszego tematu szczególnie ważne są uwagi Noldina dotyczące pomagania z racji różnego rodzaju międzyosobowych więzi. Otóż zauważa on, że byli tacy autorzy, którzy twierdzili, że preferowanie w porządku miłości osób z racji pokrewieństwa czy ludzkiej przyjaźni stanowi wykroczenie przeciw doskonałości chrześcijańskiej. Autor przeciwstawia się tym tendencjom, stwierdzając, że łaska nie niszczy natury, ale ją umacnia. Wśród tych uprzywilejowanych więzi wymienia trzy typy: cielesne (wynikające z pokrewieństwa, z małżeństwa, z powinowactwa) duchowe (wypływające z więzów wspólnoty religijnej) oraz obywatelskie (wynikające z więzów społecznych współobywatele, mieszkańcy tego samego miasta, sąsiedzi, dobrodziej). Dalej o. Hieronim precyzuje, że w przypadku równej potrzeby powinniśmy miłować bardziej osoby silniej z nami związane ${ }^{17}$. Natomiast obcemu znajdującemu się w potrzebie duchowej powinniśmy szybciej pośpieszyć z pomocą niż bliskiemu znajdującemu się w potrzebie doczesnej ${ }^{18}$.

Z powyższej prezentacji można wyprowadzić wniosek dotyczący pewnej ciągłości w nauczaniu dotyczącym ordo caritatis od św. Augustyna do czasu

16 Por. tamże, s. 80-81.

17 Do tego właśnie elementu rozumienia kategorii ordo caritatis nawiązują dwie wypowiedzi Prymasa Tysiąclecia przywołujące ordo caritatis. Słowa Kardynała Stefana Wyszyńskiego należy odczytywać w kontekście propagowania przez władze socjalistyczne kosmopolityzmu komunistycznego: „Ład w miłowaniu - ordo caritatis wymaga, aby człowiek, który staje na czele jakiejś grupy społecznej i przyjmuje na siebie odpowiedzialność za nią, pamiętał najpierw o obowiązkach wobec dzieci swego narodu, a dopiero w miarę zaspokajania i nasycania najpilniejszych, podstawowych potrzeb własnych obywateli, rozszerzał dążenie do niesienia pomocy na inne ludy i narody, na całą rodzinę ludzką" - S. Wyszyński, Drugie kazanie świętokrzyskie (20 luty 1974), www.non.possumus.pl/nauczanie (strona internetowa prezentująca nauczanie kard. Stefana Wyszyńskiego) [dostęp: 31.05.2017]. „Nie oglądajmy się więc na wszystkie strony. Nie chciejmy żywić całego świata, nie chciejmy ratować wszystkich. Chciejmy patrzeć w ziemię ojczystą, na której wspierając się, patrzymy ku niebu. Chciejmy pomagać naszym braciom, żywić polskie dzieci, służyć im i tutaj przede wszystkim wypełniać swoje zadanie - aby nie ulegać pokusie «zbawiania świata» kosztem własnej ojczyzny” - S. Wyszyński, Przemówienie do kapłanów stolicy (24 grudzień 1976), www.non.possumus.pl/nauczanie [dostęp: 31.05.2017].

${ }_{18}$ Por. H. Noldin, Summa theologiae moralis..., dz. cyt., s. 81-85. 
przed Soborem Watykańskim II. Można też zauważyć tendencję do pewnego uszczegółowiania tego zagadnienia, co - być może - wpłynęło na osłabienie zainteresowania tą kategorią.

\section{Współczesna aktualność kategorii ordo caritatis w odniesieniu jej do problemu migracji}

Rzeczywiście wydaje się, że w kontekście posoborowej odnowy personalistycznej zagadnienie ordo caritatis zeszło na drugi plan. Słuszne akcentowanie daru z siebie, przez który to dar człowiek wzrasta w człowieczeństwie, odsuwa w cień kategorię miłości siebie. Z kolei idea kręgów przynależności i przyporządkowania do Kościoła, także podkreślanie prawdy, że Kościół jest sakramentem jedności całego rodzaju ludzkiego ${ }^{19}$, przezwyciężają różnice między poszczególnymi grupami ludzi, tak bardzo akcentowane przez te miejsca w ordo caritatis, w których jest mowa o wyraźnym rozróżnianiu między poszczególnymi kręgami osób. Do tego trzeba dodać szczególną psychologizację życia codziennego, także społeczno-medialnego, sprawiającą, że współczesne działania, w tym te związane $\mathrm{z}$ dobroczynnością, wypływają często ze spontanicznego impulsu, bez refleksji racjonalnej.

$\mathrm{Z}$ drugiej jednak strony to właśnie personalizm chrześcijański szczególnie mocno podkreśla podmiotowość osoby, a z nią związaną racjonalność miłości oraz wolność działania. Właściwie rozumiana w personalizmie chrześcijańskim koncepcja miłości zawsze dystansowała się od agapizmu, np. agapizmu Johna Fletchera, w którym miłość nie miała swojego ładu czy porządku. Personalizm chrześcijański zawsze zakładał, że miłość jest postawą uporządkowaną, zbudowaną na poznaniu rozumowym oraz na wypływającej z niego wolnej decyzji. Chrześcijańska wizja miłości zakłada jej wewnętrzny ład, logikę, racjonalność, z całą stanowczością podkreśla, że nie jest to zmienna amor, ale caritas zbudowana na veritas, o czym jednoznacznie nauczał Benedykt XVI, szczególnie w encyklice Caritas in veritate. Wszystko to potwierdza, że można dziś mówić w miłości o porządku i że kategoria ordo caritatis jest stale aktualna.

Z tej perspektywy warto spojrzeć na przypowieść o dobrym Samarytaninie, jakoby stanowiącą podstawę do tworzenia normy, według której chrześcijanin ma pomagać wszystkim ludziom. Z przypowieści tej można wydobyć dwie warstwy. Pierwszą można nazwać „poryw i otwartość serca”. Dostrzega

19 Por. Sobór Watykański II, Konstytucja dogmatyczna o Kościele Lumen gentium (21.11. 1965), w: Sobór Watykański II, Konstytucje. Dekrety. Deklaracje. Tekst polski - nowe thumaczenie, Poznań 2002, nr 14-16, nr 1. 
się w niej niezwykłą spontaniczność i wrażliwość działania. Pokazują to: słowa opisujące stan emocjonalno-duchowy „wzruszył się głęboko”, następnie całe czynne zaangażowanie: opatrzenie ran, zawiezienie do gospody, czuwanie prawdopodobnie w nocy, obietnica powrotu, hojność i wielkoduszność finansowa, a także działanie ponad podziałami i uprzedzeniami narodowościowo-politycznymi. W ten sposób Samarytanin stanowi i zawsze stanowił wezwanie do zaangażowania na rzecz bliźniego, inspirował do uniwersalnej bezinteresowności; był (i jest) patronem wolontariuszy.

Istnieje jednak drugi wymiar tej przypowieści, mniej zauważany i mniej doceniany. Chodzi o „racjonalność działania”. Można spotkać się z interpretacjami tej przypowieści przeciwstawiającymi spontanicznie i wielkodusznie działającego Samarytanina wyrachowanemu działaniu właściciela gospody, który pomagał jedynie, w przeciwieństwie do Samarytanina, za pieniądze. Trudno zgodzić się z tymi interpretacjami i jeśli mówimy o „racjonalnym wymiarze pomagania”, wcale nie chodzi o gospodarza, ale właśnie o Samarytanina. Otóż, należy stwierdzić, że działał on kompetentnie i racjonalnie. Szybko przeanalizował, jakie posiada środki, i zastosował je: oliwa jako analgetyk, wino jako dezynfekcja, bydlę jako środek transportu. Były to środki doraźne, ale na dłuższą metę niewystarczające; potrzebne było komplementarne wsparcie ze strony instytucji, czyli gospody. Jeśli przekazał na opiekę pieniądze, to należy przede wszystkim stwierdzić, że on te pieniądze wcześniej posiadał: „dał, bo miał”. Jeśli był niewykwalifikowanym pracownikiem, to, dając dwa denary, przekazał pensję za dwa dni pracy. Wolontariat i bezinteresowne pomaganie nigdy nie mogą stanowić całości życia człowieka. Potrzebna jest praca „zarobkowa”, praca „na etacie”, aby możliwe było pomaganie i działanie wolontaryjne. Nie wystarczy ,poryw serca”, potrzebna jest „racjonalność działania" ${ }^{20}$. W społecznym nauczaniu Kościoła w sposób wyważony analizuje się zależność między sprawiedliwością a miłosierdziem. Czynił to zarówno Jan Paweł II, jak i Benedykt XVI.

To prawda, że przypowieść o dobrym Samarytaninie przełamuje ówczesne schematy i wskazuje na uniwersalizm miłości. Jednak nie może prowadzić do nadinterpretacji. Byłoby nią stwierdzenie, że liczy się przede wszystkim wolontariat, a nie praca na etacie, że pracę na etacie można wykonywać bez zaangażowania serca, a dopiero w wolontariacie potrzebne jest serce. Nadinterpretacją byłoby stwierdzenie, jakoby nie wolno było zająć się owymi zbójcami z przypowieści w celu ochrony bezpieczeństwa społecznego. Nadinterpretacją byłoby stwierdzenie, że gdyby przy drodze leżało dwóch poszkodowanych,

${ }^{20}$ Szeroko na temat racjonalnego wymiaru pomagania w obszarze opieki nad ludźmi terminalnie chorymi piszę w artykule The Samaritan Paradigm in modern palliative care, „Śląskie Studia Historyczno-Teologiczne" 38 (2005), numer specjalny, s. 179-189. 
przy czym jeden byłby Żydem, a drugi Samarytaninem, i obydwaj znajdowaliby się w podobnym stanie zdrowia, a przechodziłby tamtędy Samarytanin i pomógłby najpierw swojemu rodakowi, to że taka postawa miałaby posmak egoizmu czy też ksenofobii.

Po tych rozważaniach warto i trzeba jeszcze raz wrócić do samej kategorii ordo caritatis i do trzech jej płaszczyzn wydobytych przede wszystkim przez Noldina. W każdej z tych trzech płaszczyzn można rozpatrywać zarówno wymiar indywidualny miłości i pomagania, jak i społeczny. Społeczny wymiar miłości i pomagania wymaga przy tym głębszego namysłu etycznego, gdyż skutki danych postaw mają szersze oddziaływanie. Zaś w wymiarze indywidualnym zasadniczo konsekwencje zachowań mają mniejszą siłę i generalnie dotykają jednostki.

Jeśli chodzi o pierwszą płaszczyznę, powiedziano, że należy właściwie rozumieć koncepcję miłości własnej. Można ją odnieść do tego, co we współczesnym personalizmie mówi się na temat podmiotowości, wolności i odpowiedzialności zarówno pojedynczej osoby, jak i całego społeczeństwa. Z niej wynika przekonanie, że postawy dobroczynności nie można nikomu narzucić. To właśnie w imię tej zasady etyka personalistyczna wyraźnie opowiada się za zgodą rzeczywistą w dziedzinie dawstwa narządów. Można zachęcać do ofiarowania narządów, ale nie można przymuszać ani też nie można szantażować, że brak zgody na oddanie narządów może spowodować śmierć niedoszłego biorcy. Nie można postawy niewyrażenia zgody na przeszczep określać mianem egoizmu ${ }^{21}$. Można zachęcać do przyjęcia imigrantów, jednak nie można ani przymuszać, ani stosować szantażu emocjonalnego. Zasada ta dotyczy zarówno wymiaru indywidualnego (zachęty skierowanej do konkretnej osoby), jak i do określonego społeczeństwa. Dane społeczeństwo w imię własnej podmiotowości i autonomii ma prawo rozważyć, czy i w jakiej mierze chce i może wesprzeć imigrantów.

Jeśli chodzi o drugą płaszczyznę ordo caritatis, to należy podkreślić, że chodzi w niej o priorytet potrzeb duchowych nad materialnymi. W kontekście współczesnej laicyzacji życia społecznego, a także przy pewnym horyzontalizmie w pojmowaniu chrześcijańskiej cnoty miłości, przywołana wyżej norma winna być szczególnie podkreślana. W tradycyjnie rozumianym ordo caritatis zawsze podkreślano, że sposób wyświadczanej pomocy nie może być zagrożeniem dla życia moralnego (w sensie popełnienia zła). Choć kręgi przyporządkowania do Kościoła wskazują na wartość poszczególnych kultur i religii, na to, co je wiąże z Kościołem jako wspólnotą zbawienia oraz na równą

${ }^{21}$ Por. M. Machinek, Śmierć w dyspozycji czlowieka. Wybrane problemy etyczne u kresu ludzkiego życia, Olsztyn 2004, s. 38. 
godność i prawa narodów ${ }^{22}$, to jednak nie można nie zauważać poważnych zagrożeń dla chrześcijaństwa ze strony niektórych religii (lub przynajmniej elementów religii, lub też różnych wersji religii) czy kultur, szczególnie ze strony fundamentalistycznie pojmowanego islamu. To zagrożenie jest tym poważniejsze, im słabsze jest przeżywanie wiary chrześcijańskiej w przestrzeni społecznej. Zresztą w historii Kościoła zagrożenia te były wyraźnie widziane i identyfikowane oraz były w tym względzie podejmowane środki obrony. Zatem $\mathrm{w}$ kształtowaniu pomocy (szczególnie w wymiarze społecznym) ten aspekt ordo caritatis winien być uwzględniany.

Można powiedzieć, że omówione wyżej dwie płaszczyzny ordo caritatis mają wiele wspólnych cech. Wskazują mianowicie na zagadnienie podmiotowości i tożsamości społeczeństwa pomagającego. W tym miejscu można wskazać na pewne podobieństwa omawianego zagadnienia z dziedziną etyki lekarskiej. Otóż rozwój myśli w ramach etyki lekarskiej można podzielić na trzy etapy: 1 etap hipokratesowy - to etap autorytetu lekarza (czasem, $\mathrm{z}$ umniejszeniem autonomii pacjenta; czasem, to nie znaczy zawsze), 2 etap - to etap autonomii pacjenta (czasem, z umniejszeniem autonomii lekarza), 3 etap - etap klauzuli sumienia (na powrót przypominającej o autonomii lekarza). Wydaje się, że w samoświadomości europejskiej można odkryć podobne trzy etapy (czy może trzy tendencje): etap 1 - podkreślenie wartości i podmiotowości Europy, z jej chrześcijańską tożsamością (czasem, z poniżeniem wartości innych narodów), etap 2 - akcentowanie praw narodów (przynajmniej od czasu Pawła Włodkowica i jego wystąpienia na Soborze w Konstancji, ale współcześnie nierzadko z umniejszeniem własnej kultury), etap 3 - którego potrzebuje Europa - to etap sprzeciwu wobec destrukcji własnej podmiotowości, kultury i tożsamości. Zarówno do tematu etyki lekarskiej, jak i problematyki pomagania innym odnoszą się ważne uwagi zamieszczone przez Karola Wojtyłę w książce Osoba i czyn. Otóż według Wojtyły w zasadę solidarności wpisana jest zasada sprzeciwu ${ }^{23}$. To właśnie ta druga zasada stoi na straży podmiotowości osoby ludzkiej.

Wreszcie pozostaje trzecia płaszczyzna ordo caritatis, a mianowicie wielkość potrzeby. Przypomnijmy, że w tradycyjnym ujęciu wyróżniano trzy potrzeby: skrajną, ciężką i lekką. W przypadku problemu imigrantów sprawa nie jest łatwa do rozstrzygnięcia. W sytuacji konkretnego imigranta rodzi się pyta-

${ }^{22}$ W takim duchu wypowiada się Konstytucja dogmatyczna o Kościele Lumen gentium, a także soborowa Deklaracja o stosunku Kościoła do religii niechrześcijańskich Nostra aetate (28.101965). $\mathrm{W}$ tej ostatniej padają m.in. takie słowa: ,zostaje więc usunięta podstawa wszelkiej teorii lub praktyki, która pomiędzy człowiekiem i człowiekiem, pomiędzy narodem i narodem wprowadza różnice co do godności ludzkiej i wypływających stąd praw" - tamże, nr 5.

${ }^{23}$ Por. K. Wojtyła, Osoba i czyn, Lublin 199433, s. 324-325. 
nie: Czy ucieka on przed śmiercią i przed prześladowaniem (skrajna potrzeba cielesna) czy przybywa, aby poprawić swoją sytuację życiową (lekka potrzeba cielesna)? Jeśli imigrant ucieka przed śmiercią lub prześladowaniem, to winien on znaleźć pomoc poprzez przyjęcie go, przynajmniej na określony czas. Jeśli przybywa, żeby polepszyć warunki bytowe, to nie istnieje ścisły obowiązek pomocy. Ocena wymaga nieprostych narzędzi społecznych. Na pewno potrzebne jest mądre prawo azylowe. Nie ulega wątpliwości, że im większy ciężar potrzeby, tym bardziej konieczna jest jej realizacja. Na tę płaszczyznę ordo caritatis nakłada się także problem kręgów grup bliźnich wynikający z różnego typu więzów. Jak wspomniano przed chwilą: im większa potrzeba bliźniego, tym większa powinność pomocy. Z kolei, jeśli w tej samej równie poważnej potrzebie znajdują się dwie grupy bliźnich: jedna z kręgu kulturowo-religijnego bliższego, druga z kręgu kulturowo-religijnego dalszego, to $\mathrm{w}$ imię miłości rozumianej jako philadelphia oraz na mocy tego, że łaska nie niszczy natury, istnieje prawo dania priorytetu grupie bliźnich bliższych religijnie-kulturowo. Równocześnie postawa ta realizuje normy z poprzedniej płaszczyzny, w której mówiono o tym, by nie narażać własnej wiary i kultury. Postawa taka ma podłoże racjonalne, nie jest przejawem ksenofobii, nie jest wyrazem selekcji i segregacji bliźnich, z których każdy ma tę samą osobową godność.

Podsumowując, należy stwierdzić, że kategoria ordo caritatis jest stale aktualna i może być odnoszona do współczesnych problemów migracyjnych, przy czym nie stanowi ona intelektualnego narzędzia do wypracowania „chrześcijańskiej postawy niepomagania” czy też usprawiedliwienia egoizmu. Kategoria zabezpiecza przed kierowaniem się jedynie emocjami, czasem generowanymi na masową, medialną skalę, a przypomina o racjonalności pomagania i o konieczności zachowania w tym logiki oraz porządku.

\author{
RESPONSIBILITY FOR OTHERS \\ IN THE CONTEXT OF CATEGORY ORDO CARITATIS \\ (INCLUDING THE PROBLEM OF MIGRATION)
}

\title{
Summary
}

The article analyzes, present in the Christian tradition from St. Augustine, category ordo caritatis. Presents it from a historical perspective and makes an attempt to show that it is current, as well as shows the possibility of referring it to problems of migration in the contemporary world. The article emphasizes that category ordo caritatis was invoked whenever it was necessary to answer the question: how and who 
we should help in a situation when we cannot help them all? The author argues that the category ordo caritatis is still current (in a spirit of the conciliar reform) and can be related to contemporary problems of migration. This category prevents from being driven in the process of helping by only emotions, recalls the need for rational actions and the need for logic and order.

Słowa kluczowe: ordo caritatis; miłość; porządek; pomaganie; potrzeba; dobry Samarytanin

Keywords: ordo caritatis; love; order; help; need; good Samaritan

\section{BIBLIOGRAFIA}

Augustyn, De doctrina christiana - O nauce chrześcijańskiej. Tekst łacińsko-polski, tłum. J. Sulkowski, Warszawa 1989.

Bartoszek A., The Samaritan Paradigm in modern palliative care, „Śląskie Studia Historyczno-Teologiczne" 38 (2005), numer specjalny, s. 179-189.

Glombik K., Miłość Boga, bliźniego i samego siebie - przykazanie i postawa, „Teologia i Moralność" 6 (2009), s. 71-90.

Jan Paweł II, Encyklika Evangelium vitae (25.03.1995), w: Encykliki Ojca Świętego Jana Pawła II, Kraków 1996.

Jan Paweł II, Przemówienie podczas audiencji dla pielgrzymów przybyłych na kanonizację św. Rafata Kalinowskiego (18 listopad 1991), „L'Osservatore Romano” 11 (1991) nr 12, s. 25-26.

Machinek M., Śmierć w dyspozycji człowieka. Wybrane problemy etyczne u kresu ludzkiego życia, Olsztyn 2004.

Noldin H., Summa theologiae moralis iuxta codicem iuris canonici, Vol. II: De praeceptis Dei et Ecclesiae, Lipsk $1939^{26}$.

Pope S., The order of love and recent catholic ethics: a constructive proposal, "Theological Studies" 52 (1991) nr 2, s. 255-288.

Rońda J., Miłość samego siebie w kontekście życia społeczno-gospodarczego, „Sosnowieckie Studia Teologiczne" 11 (2013), s. 135-144.

Sobór Watykański II, Deklaracja o stosunku Kościoła do religii niechrześcijańskich Nostra aetate (28.101965), w: Sobór Watykański II, Konstytucje. Dekrety. Deklaracje. Tekst polski - nowe thumaczenie, Poznań 2002.

Sobór Watykański II, Konstytucja dogmatyczna o Kościele Lumen gentium (21.11.1965), w: Sobór Watykański II, Konstytucje. Dekrety. Deklaracje. Tekst polski-nowe tlumaczenie, Poznań 2002.

Tomasz z Akwinu, Suma teologiczna, t. 16: Miłość (II-II qu. 23-46), tłum. A. Głażewski, London 1967.

Vansteenberghe E., Charité. Les grandes écoles théologiques, w: Dictionnaire de Spiritualité, t. 2, cz. 1, Beauchesne-Paris 1953, k. 579-600.

Viller M., Monier-Vinard H., Charité. Charité envers le prochain, w: Dictionnaire de Spiritualité, t. 2. cz. 1, Beauchesne-Paris 1953, k. 649-661.

Wojtyła K., Osoba i czyn, Lublin $1994^{3}$.

Wyszyński S., Drugie kazanie świętokrzyskie (20 luty 1974), www.non.possumus.pl/ nauczanie (strona internetowa prezentująca nauczanie kard. Stefana Wyszyńskiego) [dostęp: 31.05.2017].

Wyszyński S., Przemówienie do kapłanów stolicy (24 grudzień 1976), www.non.possumus.pl/nauczanie [dostęp: 31.05.2017]. 


\begin{abstract}
Antoni BARToszeK - prezbiter archidiecezji katowickiej, teolog moralista; adiunkt w Katedrze Nauk o Rodzinie Wydziału Teologicznego Uniwersytetu Śląskiego w Katowicach; aktualnie dziekan Wydziału; autor książek, m.in: Człowiek w obliczu cierpienia i umierania. Moralne aspekty opieki paliatywnej, Katowice 2000; Seksualność osób niepetnosprawnych. Studium teologicznomoralne, Katowice 2009; autor ok. 60 artykułów naukowych. Specjalizuje się w teologii moralnej, szczególnie teologii moralnej społecznej oraz w naukach o rodzinie. Równocześnie od wielu lat pełni posługę kapelana w Ośrodku dla Niepełnosprawnych Najświętsze Serce Jezusa w Rudzie Śląskiej.
\end{abstract}

